\title{
New record and larval habitats of Culex eduardoi (Diptera: Culicidae) in an irrigated area of Patagonia, Chubut Province, Argentina
}

\author{
Nora Burroni/+, Verónica Loetti, Gabriela Freire, Oscar Jensen*, Nicolás Schweigmann**
}

Grupo de Estudio de Mosquitos, Departamento de Ecología Genética y Evolución, Facultad de Ciencias Exactas y Naturales, Universidad de Buenos Aires, Pabellón II, Ciudad Universitaria, Int. Güiraldes 2620 C1428EHA, Ciudad Autónoma de Buenos Aires, Argentina *Departamento Zooantroponosis, Ministerio de Salud, Provincia de Chubut, Argentina **Consejo Nacional de Investigaciones Científicas y Tecnológicas, Buenos Aires, Argentina

The object of the present work was to identify the larval habitats of Culex eduardoi and to determine the microenvironmental conditions related to their presence in different artificial freshwater environments (temporary, semi-permanent, irrigation ditches, and drainage ditches) in tillable areas of Chubut Province, Argentina. This report represents the first record of $\mathrm{Cx}$. eduardoi from this Province and extends its range to latitude $45^{\circ} \mathrm{S}$. Immature stages of $\mathrm{Cx}$. eduardoi were found in 8 out of $109(7.3 \%)$ freshwater habitats and were significantly more prevalent in semi-permanent water bodies. Positive sites had significantly larger surface areas and more vegetation cover than negative sites.

Key words: aquatic vegetation - larval habitats - Culicidae - Culex eduardoi - Patagonia

Human-caused environmental disturbances may alter the population dynamics of some mosquito species (Barrera et al. 1979) or create suitable conditions for their proliferation (Gomes 1986, Lopes \& Lozovei 1995, Robert et al. 1998). Many studies conducted in different world regions have shown a link between availability of mosquito larval habitats and anthropogenic activities in tillable areas (Forattini et al. 1993, Robert et al. 1998, Herrel et al. 2001). Artificial irrigation systems in both rural and urban arid regions may create freshwater environments that are suitable for mosquito immatures. Irrigation systems implemented in Sarmiento village, Chubut Province (Patagonia, Argentina) provide an example for this study. Only two species of mosquito, Culex pipiens and Ochlerotatus albifasciatus, are known to occur in Chubut Province (Mitchell \& Darsie 1985), and the present study reports the first finding of Culex eduardoi. Studies on ecology of Culicidae from Patagonia are scarce and, in particular, no information is available on environmental characteristics of larval habitats.

The characterization of mosquito larval habitats based on biological, physical, and chemical features is important for understanding the complex interactions among immatures and the biotic and abiotic components of their aquatic environment (Laird 1988). In addition, the knowledge of both their aquatic habitats and the factors that constrain the ecological distribution of mosquitoes is of potential epi-

\footnotetext{
+ Corresponding author.nburroni@ege.fcen.uba.ar Received 23 October 2006 Accepted 31 January 2007
}

demiological interest (Forattini 1965), because many mosquito species have been incriminated in the transmission of important human and animal diseases.

The object of the present work was, therefore, to identify larval habitats of $C x$. eduardoi and to determine characteristics related to their presence in Chubut Province, Argentina.

The village of Sarmiento $\left(45^{\circ} 35^{\prime} \mathrm{S}-69^{\circ} 05^{\prime} \mathrm{W}\right)$ is located on the floodplain of the Senguer River, in the center of the Patagonian plateau, Chubut Province, Argentina. The landscape is dominated by steppe (Cabrera 1971) and the temperate climate is dry and cold (Paruelo et al. 1999). In January 2003 air temperature was varied in the range $12.6^{\circ} \mathrm{C}$ to $24.8^{\circ} \mathrm{C}$ (mean temperature $18.5^{\circ} \mathrm{C}$ ) and accumulated precipitation was $0.87 \mathrm{~mm}$ (NOAA). There are a few lentic freshwater environments, which are fed by rainfall and melting ice during summer.

The main economic activities of the village are agriculture and cattle raising, and the productivity of farmlands has been improved after the implementation of an irrigation system fed by the Senguer River. It consists of a network of irrigation and drainage ditches, and the volume of water delivered to each farm is controlled by opening and closing the ditches. At the time of the study, about 12,606 ha (comprising $22 \%$ of the total village area) were irrigated by this method. The artificial flood regime takes place from mid-spring to mid-autumn, and farmlands are irrigated more than twice during this period due to water loss by evaporation.

Different artificial freshwater environments in the urban and rural areas of Sarmiento were surveyed in the austral summer from January 9-24, 2003. Aquatic environments were classified into the following four major categories: temporary water bodies, semi-permanent water bodies, irrigation ditches, and drainage ditches. The water surface area, the depth, and the percent of vegetation covering were estimated for each freshwater habi- 
tat. The surface area was estimated by measuring the area of a rectangle containing the water body, multiplied by the percentage of this geometric shape covered by water. The percent of vegetation covering the water surface was estimated visually.

The following physical and chemical variables of the water were also recorded: water turbidity, $\mathrm{pH}$ (measured with a digital $\mathrm{pH}$ meter $\mathrm{pHep}$-Hanna), dissolved oxygen (measured with a digital oximeter Lutron CD-4303), salinity (measured with a portable refractometer VISTA A366ATC), and temperature (measured with a digital thermometer TFA). Turbidity was estimated by placing 51 of water sample in a white container $(20 \mathrm{~cm}$ diameter by $15 \mathrm{~cm}$ deep), and classified in three levels: $1=$ turbid, $0.5=$ semitransparent, and $0=$ clear water. Turbid samples were those where the white container background could not be seen.

To collect immatures, one sample was taken from each environment with a $350 \mu \mathrm{m}$ mesh hand-net. Each sample was composed for a numbers of dips. The number of dips was proportional to the surface area of each habitat. Each dip measured $1 \mathrm{~m}$, with 0.5 dips for surfaces from 0.1 to 1 $\mathrm{m}^{2}$ and 18 for surfaces higher than $1000 \mathrm{~m}^{2}$ (Fontanarrosa et al. 2004). In all cases, the material collected was fixed in situ with $80 \%$ ethanol. Preimaginal mosquitoes were identified with an appropriate key (Darsie 1985). The other species detected was Oc. albifasciatus, but this did not constitute part of this study.

The numbers of habitats positive for $C x$. eduardoi in each aquatic environment category were compared with larva-negative sites by mean of test for independent proportions, whose value of the statistic may be referred to tables of chi squares (Fleiss 1981). Habitat characteristics of larva-positive and negative sites for $C x$. eduardoi were compared using Mann-Whitney U-tests (Zar 1996).

Immature stages of $C x$. eduardoi were found in 8 out of $109(7.3 \%)$ freshwater environments (Table I).

Eight percent of the freshwater habitat contained $C x$. eduardoi in the rural area, while no larva-positive sites were detected in the urban area. Higher prevalence in semi-permanent water bodies contributed to significantly different occupancy by this species of the four habitat types $\left(\chi_{(3)}^{2}=45.31, \mathrm{p}<0.001\right)$. Vegetation commonly found in these environments were rooted aquatic plants such as like bulrushes (Schoenoplectus sp.) and cattails (Typha sp.), and free-floating aquatic plants in-
TABLE I

Number of larva-positive sites respect to examined aquatic sites for each category in rural and urban areas, January 2003, village of Sarmiento, Chubut Province, Argentina

\begin{tabular}{lcc}
\hline & \multicolumn{2}{c}{ Areas } \\
\cline { 2 - 3 } Freshwater environments & Rural & Urban \\
\hline Temporary & $1 / 69$ & $0 / 6$ \\
Semi-permanent & $6 / 10$ & $0 / 0$ \\
Irrigation ditches & $0 / 5$ & $0 / 1$ \\
Drainage ditches & $1 / 16$ & $0 / 2$ \\
\hline Total & $8 / 100$ & $0 / 9$ \\
\hline
\end{tabular}

cluding water ferns (Azolla sp. and Salvinia sp.) and duckweeds (Lemna sp. and Wolffiella sp.).

Positive sites had a median area of approximately $4700 \mathrm{~m}^{2}$, significantly more than negative sites $\left(\mathrm{U}_{7.81}=\right.$ $153.5, \mathrm{p}<0.05)$, and a vegetation cover higher than $90 \%$ significantly more than negative sites $\left(\mathrm{U}_{8,101}=155, \mathrm{p}<\right.$ 0.01 ). No statistically significant differences were found between positive and negative sites with respect to $\mathrm{pH}$, dissolved oxygen, salinity, temperature, turbidity, and depth of the water column (Table II).

The present paper extends the geographic range of $C x$. eduardoi to latitude $45^{\circ} \mathrm{S}$, its previously known southern distribution limit was at $34^{\circ} 55^{\prime} \mathrm{S}$ in Buenos Aires Province, Argentina (Mitchell \& Darsie 1985). This is the first report of larval mosquito sites associated with anthropogenic activity in tillable areas of Southern Argentina. In Sarmiento, the number of freshwater habitats with stagnant or slow-moving water has been increased by the flood irrigation method, thus increasing the availability of larval sites for mosquitoes such as Cx. eduardoi.

The immature stages of $C x$. eduardoi are found in a wide variety of freshwater environments in temperate and tropical regions, that include natural temporary (Casal \& García 1968, Fischer et al. 2000, Oria et al. 2002), natural permanent and semi-permanent environments (Forattini et al. 1993, Lopes \& Lozovei 1995, Oria et al. 2002), and different types of artificial containers (Lopes 1997).

Our results suggest that the water surface area and the percentage of aquatic vegetation cover may affect the selection of oviposition sites by $C x$. eduardoi. The

TABLE II

Values of microenvironmental variables (median and interquartile range) in positive and negative sites for Culex eduardoi

\begin{tabular}{|c|c|c|c|c|c|c|}
\hline \multirow[b]{2}{*}{ Variables } & \multicolumn{3}{|c|}{ Positive sites } & \multicolumn{3}{|c|}{ Negative sites } \\
\hline & $\mathrm{N}$ & Median & Q1 - Q3 & $\mathrm{N}$ & Median & Q1 - Q3 \\
\hline $\mathrm{pH}$ & 8 & 7.60 & $7.26-8.76$ & 91 & 8.40 & $7.71-9.26$ \\
\hline Dissolved oxygen (mg/l) & 8 & 5.45 & $4.70-7.13$ & 92 & 7.35 & $5.38-10.63$ \\
\hline Salinity $(\% o)$ & 8 & 8.00 & $2.00-9.00$ & 91 & 8.00 & $3.00-9.00$ \\
\hline Temperature $\left({ }^{\circ} \mathrm{C}\right)$ & 8 & 20.53 & $19.08-21.11$ & 94 & 19.93 & $17.60-23.64$ \\
\hline Turbidity & 8 & 0.25 & $0-0.50$ & 97 & 0.00 & $0-0.50$ \\
\hline Surface area $\left(\mathrm{m}^{2}\right)^{a}$ & 7 & 4674.00 & $1531.50-8000.00$ & 81 & 273.00 & $39.04-1050.00$ \\
\hline Depth (cm) & 8 & 32.50 & $27.50-40.00$ & 99 & 25.00 & $15.00-40.00$ \\
\hline Vegetation cover $(\%)^{b}$ & 8 & 0.98 & $0.88-1.00$ & 101 & 0.50 & $0.10 .-0.90$ \\
\hline
\end{tabular}

Significant differences by Mann-Whitney U test $(a: \mathrm{p}<0.05, b$ : $\mathrm{p}<0.01)$. 
water surface area would be related directly with its degree of permanence, which in turn would favour vegetation cover. Vegetation cover is likely to provide shelter from the wind during oviposition, and food resources (Schneider \& Frost 1996) and protection from predators of immatures (Laird 1988).

The ocurrence of immature stages of $C x$. eduardoi throughout the year has been documented in Buenos Aires City, Argentina (Fischer et al. 2000) and in Southern Brazil (Lopes 1997). According to Lopes (1997), the presence of this species throughout the year may reflect an adaptive response to a wide range of thermal conditions. Thus, it may be reasonable to assume that the adaptive capacity of this species might account for its occurrence at latitudes as high as $\sim 45^{\circ} \mathrm{S}$. Among the mosquito species present in southern South America, Cx. eduardoi, together with Oc. albifasciatus and Cx. pipiens (Mitchell \& Darsie 1985), would appear to be the best adapted to cold and arid environmental conditions.

\section{ACKNOWLEDGEMENTS}

To the people of Sarmiento, to the staff of the Hydatid Control Program of the Chubut Province, and to the Consejo Deliberante of Sarmiento for their kind cooperation and hospitality.

\section{REFERENCES}

Barrera RR, Machado-Alison CE, Bulla LA 1979. Criaderos, densidad larval y segregación de nicho en tres Culicidae urbanos (Culex fatigans Wied., C. corniger Theo., y Aedes aegypti L.) en el cementerio de Caracas. Acta Cient Venezol 30: 418-424.

Cabrera AL 1971. Fitogeografía de la República Argentina. Bol Soci Argentina de Botánica 14: 1-43.

Casal OH, García M 1968. Culex (Culex) eduardoi, una nueva especie de la República Argentina (Diptera, Culicidae). Rev Soc Ent Arg 30: 105-111.

Darsie Jr RF 1985. Mosquitoes of Argentina. Part I. Keys for identification of adult females and fourth stage larvae in English and Spanish (Diptera, Culicidae). Mosq Syst 17: 153-253.

Fischer S, Marinone MC, Fontanarrosa MS, Nieves M, Schweigmann N 2000. Urban rain pools: seasonal dynamics and entomofauna in a park of Buenos Aires. Hydrobiologia 441: 45-53.

Fleiss JL 1981. Statistical Methods for Rates and Proportions, John Wiley \& Sons, USA, 255 pp.

Fontanarrosa MS, Torres PL, Michat MC 2004. Comunidades de insectos acuáticos de charcos temporarios y lagunas en la ciudad de Buenos Aires (Argentina). Rev Soc Entomol Argent 63: 55-65.
Forattini OP 1965. Entomología Médica. 2. Culicini: Culex, Aedes, Psorophora, Universidade de São Paulo, São Paulo, $506 \mathrm{pp}$.

Forattini OP, Kakitani I, Massad E, Marucci D 1993. Studies on mosquitoes (Diptera: Culicidae) and anthropic enviroment. 2 - Immature stages research at a rice irrigation system location in South-Eastern Brazil. Rev Saúde Pública 27: 227-236.

Gomes A de C 1986. Mecanismos e significado epidemiológico da domiciliação. Rev Saúde Pública 20: 385-390.

Herrel N, Amerasinghe FP, Ensink J, Mukhtar M, Van Der Hoek W, Konradsen F 2001. Breeding of Anopheles mosquitoes in irrigated areas of south Punjab, Pakistan. Med Vet Entomol 15: 236-248.

Laird M 1988. The Natural History of Larval Mosquito Habitats, Academic Press, London, 555 pp.

Lopes J 1997. Ecologia de mosquitos (Diptera, Culicidae) em criadouros naturais e artificias de área rural no norte do Estado do Paraná, Brasil. VII. Coexistência das espécies. Iheringia Sér Zool Porto Alegre 83: 91-97.

Lopes J, Lozovei AL 1995. Ecologia de mosquitos (Diptera: Culicidae) em criadouros naturais e artificias de área rural do norte de Estado do Paraná, Brasil. I - Coletas ao longo do leito de ribeirão. Rev Saúde Pública 29: 183-191.

Mitchell CJ, Darsie Jr RF 1985. Mosquitoes of Argentina. Part. II. Geographic distribution and bibliography (Diptera, Culicidae). Mosq Syst 17: 279-236.

NOAA Satellite and Information Service. National Climatic Data Center U.S., Departament of Commerce, NNDC Climate Data Online. Available online at http://cdo.ncdc.noaa. gov/CDOredirector?datasetabbv=GSOD $\&$ georegionabbv $=$ \&countryabbv $=$

Oria G, Stein M, Gorodner JO 2002. Mosquitos, sus criaderos y factores socioculturales de la población en el Nordeste Argentino. In OD Salomón, Actualizaciones en Artropodología Sanitaria Argentina, Publicación Monográfica 2, Buenos Aires, p. 167-172.

Paruelo JM, Beltrán A, Jobbágy E, Sala EO, Golluscio RA 1999. The climate of Patagonia: general patterns and controls on biotic processes. Ecología Austral 8: 85-101.

Robert V, Awono-Ambene HP, Thioulouse J 1998. Ecology of larval of mosquitoes, with special reference to Anopheles arabiensis (Diptera: Culicidae) in market-garden wells in urban Dakar, Senegal. J Med Entomol 35: 948-955.

Schneider DW, Frost TM 1996. Habitat duration and community structure in temporary ponds. J N Am Benth Soc 15: 64-86.

Zar JH 1996. Biostatistical Analysis, 3rd ed., Prentice-Hall, New Jersey, 662 pp. 
